\title{
Salmonella Yoruba infection in white-tufted-ear marmoset (Callithrix jacchus) $^{1}$
}

\author{
Terezinha Knöbl ${ }^{2 *}$, Leliane T. Rocha ${ }^{3}$, Márcia C. Menão ${ }^{3,4}$, Cláudia A.S. Igayara ${ }^{5}$, \\ Renata Paixão ${ }^{2}$ and Andréa M. Moreno ${ }^{2}$
}

\begin{abstract}
Knöbl T., Rocha L.T., Menão, M.C., Igayara C.A.S., Paixão, R. \& Moreno A.M. 2011. Salmonella Yoruba infection in white-tufted-ear marmoset (Callithrix jacchus). Pesquisa Veterinária Brasileira 31(8):707-710. Faculdade de Medicina Veterinária da Universidade do Grande ABC, Avenida Industrial 3330, Santo André, SP 09080-511, Brazil. E-mail: tknobl@fmu.br

The aim of this study was to describe a fatal salmonellosis case in a non-human female primate (Callithrix jacchus), found in the illegal pet trade in Brazil. The marmoset was sent to the quarantine section of the Guarulhos City Zoo and died in the sequence of an episode of profuse diarrhea. Necropsy findings included mucous enteritis, and liver enlargement and necrosis. Feces and liver fragments were collected for bacteriological tests, which indicated the presence of Salmonella sp.; it was subsequently characterized as pertaining to the Yoruba serotype. The susceptibility profile demonstrated resistance to tetracycline only. The strain was positive for genes that encoded the virulence factors investigated (invA, sefC, pefA and $s p v \mathrm{C}$ ). The results indicated the risk of introduction of Salmonella pathogenic serotypes in primates in captivity.
\end{abstract}

INDEX TERMS: Salmonella Yoruba, Callithrix jacchus, Neotropical Primate, salmonellosis, zoonosis.

RESUMO-- [Infecção por Salmonella Yoruba em sagui-detufo-branco (Callithrix jacchus).] 0 objetivo deste trabalho foi descrever um caso fatal de salmonelose em uma fêmea primata não humana (Callithrix jacchus), originária de tráfico ilegal no Brasil. O sagui foi enviado para seção de quarentena do Zoológico Municipal de Guarulhos e morreu após um episódio de diarréia profusa. Achados de necropsia incluíram enterite mucosa, hepatomegalia e necrose do fígado. Fezes e fragmentos do fígado foram coletados para testes bacteriológicos e indicaram a presença de Salmonella sp.; subsequentemente caracterizada como sorotipo Yoruba. 0 perfil de suscetibilidade mostrou resistência somente à tetraciclina. A cepa foi positiva para os genes que codificam os fatores de virulência investigados (invA, sefC, pefA and $s p v C)$. Os resultados indicaram o risco de introdução de sorotipos patogênicos de Salmonella por primatas em cativeiro.

\footnotetext{
${ }^{1}$ Received on July 9, 2010.

Accepted for publication on April 9, 2011.

2 Faculdade de Medicina Veterinária e Zootecnia (FMVZ), Universidade de São Paulo (USP), Av. Prof. Dr Orlando Marques de Paiva 87, São Paulo, SP 05508270, Brazil.*Corresponding author: tknobl@fmu.br; veterinaria.tk@gmail.com

${ }^{3}$ Laboratório de Epidemiologia e Doenças Infecciosas, Faculdades Metropolitanas Unidas (FMU), Av. Santo Amaro 1239, São Paulo, SP 04505-002, Brazil.

${ }^{4}$ Faculdade de Medicina Veterinária, Universidade do Grande ABC (UNIABC), Av. Industrial 3330, Santo Andé, SP 09080-511, Brazil.

4 Zoológico Municipal de Garulhos, Av. Dona Glória Pagnoncelli 344, Guarulhos, SP 07081 120, Brazil.
}

TERMOS DE INDEXAÇÃO: Salmonella Yoruba, Callithrix jacchus, Primatas Neotropicais, salmonelose, zoonoses.

\section{INTRODUCTION}

White-tufted-ear marmosets (Callithrix jacchus), also know as common marmosets, belong to the Callithichidae family and are characterized by their small size $(350-400 \mathrm{~g})$. They live in extended family groups and eat fruit, insects, nectar and tree exudates (gum, sap, latex) (Verona \& Pissinatti 2006).

The Callithrix jacchus species is relatively widely distributed and is listed by the World Conservation Union as least concern (IUCN 2008). The common marmoset naturally occurs in the Brazilian Atlantic forest, the scrub forest of north-eastern Brazil (caatinga), and the bush savanna of central Brazil (Cerrado). White-tufted-ear marmosets are very adaptable primates and have been introduced into many areas, such as Tijuca Forest (Rio de Janeiro), Bahia, São Paulo and Argentina. They compete for food with other native marmosets ( $C$. penicillata and $C$. aurita) and produce hybrid animals (Brasil 2011).

The maintenance of neotropical primates as pets in the household is also very common pratices in Brazil, and captured animals are sold along the highways. Members of this species are commonly captured in urban parks. The proximity of these marmosets to urban settlements, added to the common practice of capturing and keeping them as pets 
represent a considerable risk of zoonosis transmission (Chomel et al. 2007). White-tufted-ear marmosets were determined to be the source of infection for eight cases of rabies caused by a new rabies virus variant in the state of Ceará, Brazil, from 1991 through 1998 (Favoretto et al. 2001).

According Verona \& Pissinatti (2006) marmosets are associated with the spread of several viral zoonosis, including rabies, herpesvirosis, hepatitis and flavivirus infection. Among bacterial diseases with zoonotic potential, infections caused by Mycobacterium sp., Salmonella sp., Shigella sp., Campylobacter sp., Yersinia sp. and enteropathogenic Escherichia coli stand out (Joslin 2003).

Salmonelloses are the most common infectious diseases, and affect about 10 to $15 \%$ of non-human primates kept in captivity, representing about one third of spontaneous deaths in young monkeys (Paul-Murphy 1993). Several outbreaks caused by Salmonella spp. infection in captive non-human primates have been reported in zoo collections, favored by food contamination with feces of rodents and birds, with free access to the animal facilities. $S$. Typhimurium, $S$. Stanley and $S$. Enteritidis are the most common pathogenic serotypes isolated from non-human primates (Paul-Murphy 1993).

Typical salmonellosis symptoms in marmosets include enteritis, dehydration and electrolytic imbalances. In severe cases, hepatitis, septicemia and death may intervene (Verona \& Pissinatti 2006). A high percentage of survivors become long-time carriers, with fecal excretion of the infectious agent. Apparently healthy monkeys may function as an infection source for others animals (Joslin 2003).

Identified carriers in zoos should be treated, in view of public health hazards. In general, salmonella strains are sensitive to commonly available antibiotics. The drugs considered effective against these microorganisms included chloramphenicol, florfenicole, ampicillin, cephalotin, cephazolin, fluoroquinolones and sulfamethoxazoleDthrimethoprim (Cook et al. 2004).

The objective of this report is to describe a fatal case of Salmonella Yoruba infection in a marmoset living in the Guarulhos Zoo (Brazil), and to characterize the isolate by antibiotic profile and PCR for the virulence factors.

\section{MATERIALS AND METHODS}

In September 2007, an about one-year-old female marmoset (Callithrix jacchus was confiscated from the illegal pet trade and sent to the quarantine section of the Guarulhos City Zoo (SP, Brazil). The animal suffered an episode of profuse diarrhea and died four days after arrival. Necropsy findings included hyperemia and the presence of mucus in intestinal mucosal surfaces, enlargement and disseminated liver necrosis.

Feces and liver fragments were collected for bacteriological examination. The samples were separately placed in tubes containing $0.1 \%$ buffered peptone water, and incubated at $37^{\circ} \mathrm{C}$ for $24 \mathrm{~h}$. for pre-enrichment. Subsequently, the samples were transferred to sodium tetrathionate broth (selective enrichment) and incubated for $24 \mathrm{~h}$. at $42^{\circ} \mathrm{C}$, followed by subculture onto selective XLD agar media (Difco ${ }^{\mathrm{TM}}$, Becton Dick-Enson and Company, Sparks, Maryland, USA). Agar plates were incubated at $37^{\circ} \mathrm{C}$ for $24-48 \mathrm{~h}$. (Michael et al. 2003). Suspect colonies were then selected for biochemistry identification. Species identification was carried out by using conventional biochemical tests (Newprov, PR, Brazil), TSI, EPM, MiLi and Simmons citrate. Isolates were submitted to slide agglutination tests using commercial polyvalent antiserum " $O$ " and " $\mathrm{H}$ " (Probac, Brazil) and were sent to the Adolfo Lutz Institute (São Paulo, SP) for serotyping.

The antibacterial activities of chloramphenicol, gentamycin, sulfamethoxazole" thrimethoprim, enrofloxacin and tetracycline were determined by the Kirby-Bauer diffusion test (Bauer et al. 1966).

Polymerase chain reaction (PCR) procedure was developed after DNA extraction in compliance with the protocol described by Boom et al. (1990). Reaction mixtures $(50 \mu \mathrm{L})$ contained PCR buffer (1X), $\mathrm{MgCl}_{2}$ (1.5 mM), $200 \mathrm{mM}$ of each deoxyribonucleotide (dATP, dCTP, dGTP, dTTP), 50 pmol of each oligonucleotide, $1.0 \mathrm{U}$ of Taq DNA polymerase (Invitrogen, NY), autoclaved ultra pure water and 10uL of DNA template. Primers for specific amplification, annealing temperatures, fragment size and references are described in Table 1.

The Salmonellla Typhimurium ATCC 14028 was taken as positive control, while a K12 strain of Escherichia coli K12 was taken as negative control.

The amplified products were separated by electrophoresis in $1.5 \%$ agarose gel and stained with ethidium bromide. The $100 \mathrm{bp}$ DNA ladder (Life Technologies, NY) was used as a molecular size marker.

\section{RESULTS}

Black colonies (with a red background) grew on XLD agar. The biochemical findings were compatible with the Salmonella genus. Serological tests with polyvalent serum anti "O" and " $\mathrm{H}$ " confirmed the identification of the Salmonella genus. This isolate was classified as Salmonella Yoruba serotype.

Antimicrobial sensitivity patterns revealed a susceptible profile for enrofloxacin, sulfamethoxazole + thrimethoprim, chloramphenicol and gentamycin. The strain was resistant to tetracycline only.

The polymerase chain reaction showed virulence genes inv, sefC, pefA e spvC amplification.

Table 1. Primers used for PCR amplification of virulence genes of Salmonella Yoruba, isolated from marmoset (Callithrix jacchus)

\begin{tabular}{|c|c|c|c|c|}
\hline Genes & Primers 5'-3' (sense e antisense) & $\begin{array}{c}\text { Expected } \\
\text { product }\end{array}$ & $\begin{array}{l}\text { Annealing } \\
\text { temperature }\end{array}$ & References \\
\hline$s p v \mathrm{C}$ & $\begin{array}{l}\text { CGGAAATACCATCTACAATA } \\
\text { CCCAAACCCATACTTACTCTG }\end{array}$ & 669 & 42 & Swamy et al. 1992 \\
\hline $\operatorname{sefC}$ & $\begin{array}{l}\text { GCGAAAACCAATGCGACTGTAG } \\
\text { CCCACCAAGAAACATTCATCCC }\end{array}$ & 1103 & 50 & Bäumler et al. 1997 \\
\hline pefA & $\begin{array}{l}\text { AGGGAATTCTTCTTGCTTCCATTCCATTATTGCACTGGG } \\
\text { TCTGTCGACGGGGGATTATTTGTAAGCCACT }\end{array}$ & 520 & 50 & Bäumler et al. 1997 \\
\hline $\operatorname{invA}$ & $\begin{array}{l}\text { GTGAAATTATCGCCACGTTCGGGCAA } \\
\text { TCATCGCACCGTCAAAGGAACC }\end{array}$ & 284 & 64 & Salehi \& Mahzounieh 2005 \\
\hline
\end{tabular}

Pesq. Vet. Bras. 31(8):707-710, agosto 2011 


\section{DISCUSSION}

Salmonella Yoruba had never been isolated from primates. The serotypes isolated from non-human primates at the moment were $S$. Enteritidis, $S$. Typhimurim, $S$. Choleraesuis, $S$. Anatum, $S$. Stanley, $S$. Derby, $S$. Oranienburg, $S$. Sandiego, $S$. Bareilly, $S$. Braenderup, $S$. Miami, $S$. Worthington, $S$. Manhattan, $S$. Newport, $S$. Sundsvall, $S$. Heidelberge and $S$. Javiana (Paul-Murphy 1993, Montali \& Bush 1999, Joslin 2003, Speck et al. 2007).

$S$. Yoruba has been associated with contamination of the raw material used in animal ration manufacturing, involving particularly soybean-derived feed (Häggblom et al. 2002). $S$. Yoruba was detected for the first time in 1999, in the Swedish salmonella control program in imported soybean meal. In 2000, two poultry flocks were found positive for S. Yoruba and the bacterial spread among commercial farms. In some European countries, $S$. Yoruba is considered "an emergent pathogen" by the poultry industry, thus becoming a hard management issue, since this serotype can resist to the heat treatment employed in pelleting process (Osterberg et al. 2001, Häggblom et al. 2002).

$S$. Yoruba is an "exotic" serotype in Brazil and this report alerts for the need of epidemiological monitoring, in order to prevent this serotype to bring forth economic losses in the poultry and pork industry, as it has happened after the introduction of Salmonella Enteritidis in 1997. It is important to observe that, nowadays, notification of serotypes S. Pullorum, S. Gallinarum, S. Typhimurium and S. Enteritidis in poultry farms is compulsory, in compliance with the National Avian Health (Brasil 2011).

Besides the economic impact that the introduction of this serotype in Brazil may represent, the public health risk related to the contact and exposure of infected primates in the zoological garden must be highlighted. In this case, once the primate had been retrieved from the illegal pet trade, its previous disease history was unknown. Wildlife trade is associated to disease transmission at levels that not only cause human disease outbreaks but also threaten livestock, international trade, rural livelihoods, native wildlife populations, and ecosystem health. Worldwide, an estimated 40,000 primates are traded alive each year. The international wildlife trade is estimated to amount to a US\$6-billion industry. Although considered a criminal activity, wildilife illegal trade is the third largest illicit activity in the world, and it more often than not results in the death of most of the animals captured (Chomel et al. 2007).

It is impossible to determine the source of infection, because the monkey could have been infected by contact with other animals or by contaminated feed ingestion. However, one can assume that the transportation stress and poor hygiene conditions in captivity favored the development of infection and clinical signs (Clarke \& Gyles 1986).

The introduction of animals in captivity always represents a sanitary risk. However, this risk can be minimized with the implementation of the quarantine, through the condition of the animal can be investigated with laboratorial support. The existence of quarantine is ensured by normative ruling IN04/2002 and is a requirement for all Brazilian zoos (Brasil 2011). However, a specific protocol for quarantine of primates has not been established, and the investigation of some diseases often becomes economically unviable. Vilani (2006) suggests that quarantine of primates should vary between 60-90 days and that the animals should be tested for the detection of herpesvirose B, parainfluenza, reovirus, cytomegalovirus and yellow fever. The Paulista Zoological Society (SPZOO) recommends quarantine of at least 30 days and testing of primates for hemoparasites, endo and ectoparasites, tuberculosis and Salmonella sp., Shigella sp., Yersinia sp. and Campylobacter sp. (SPZOO 2011) should always be carried out.

The virulence offered by Salmonella Yoruba to humans and animals are unclear. However, experimental inoculation of pigs showed that the excretion of $S$. Yoruba presented the same pattern of $S$. Typhimurium, and it is dose-dependend. Antibody responses are slower and occur at lower titres (Österberg \& Wallgren 2008). The polymerase chain reaction (PCR) of this isolated showed the presence of virulence genes involved in adherence process and cellular invasion, suggesting virulence potential of the isolated strain. According to the literature, SEF14 and PEF proteins, encoded by sefC and pefA genes, play an important role in Peyer's patch colonization, as well as erythrocytes adhesion and invasion. The operon $s p v$ is associated with intracellular replication and bacterial survival in the endothelial system, liver and kidneys (Clarke \& Gyles 1986, Feutrier et al. 1988, Bäumler et al. 1996, Ogunniyi et al. 1997). Molecular tests that used an invA gene, which is highly preserved in Salmonella spp., were fast, efficient and also enabled the determination of the zoonotic potential and the virulence of Salmonella strain (Salehi et al. 2005, Castilla et al. 2006).

Molecular techniques proved to be useful for salmonellosis diagnosis in animals, due to their high sensitivity and specificity, beyond the possibility of detection of the genes associated with bacterial virulence (Castilla et al. 2006). PCR can be very useful for identifying the agent in asymptomatic animals and convalescent carriers (Clarke \& Gyles 1986, PaulMurphy 1993, Salehi et al. 2005, Rocha et al. 2006).

$\mathrm{R}$ plasmid presence is associated with multiple antibiotic resistance patterns in Salmonella (Paul-Murphy 1993). PaulMurphy (1993) reported strains of Salmonella resistant to ampicillin, erythromycin, chloramphenicol, tetracycline, kanamycin and dihidroestreptomycin. This study showed that $S$. Yoruba was resistant to tetracycline only.

In conclusion, our findings reinforce the importance of salmonellosis in primates and the risk of spread of new serotypes through contact with marmosets. The possibility of these primates functioning as reservoirs for agents with zoonotic potential is very high, and they should not be kept as pets. The maintenance of these animals in zoos should be very careful and follow strict health criteria to prevent the spread of infectious diseases.

To the author's knowledge, this is the first fatal case of Salmonella Yoruba infection in a non-human primate. $S$. Yoruba had never been isolated in domestic or wild animals in Brazil. Epidemiological surveys were necessary, in order to establish the importance of this agent for captive primates. 


\section{REFERENCES}

Bauer A.W., Kirby W.M., Sherris J.C. \& Turck M. 1966. Antibiotic susceptibility testing by standardized single disc method. Am. J. Clin. Pathol. 45:493-496.

Bäumler A.J., Tsolis R.M., Bowe F.A., Kusters J.G., Hoffmann S. \& Heffron F. 1996. The pef fimbrial Salmonella Typhimurium mediates adhesion to murine small intestine and is necessary for fluid operon of the infant mouse. Infect. Immun. 64:61-68.

Boom R., Sol C.J.A \& Salimans M.M.M.. 1990. Rapid and simple method for purification of nucleic acids. J. Clin. Microbiol. 28:459-453.

Brasil 2011. Programa Nacional de Sanidade Avícola. Ministério da Agricultura, Pecuária e Abastecimento <www.agricultura.gov.br/portal/ page?_pageid=33...dad>. Accessed on January 4, 2011.

Brasil 2011. Instrução Normativa no.4, de 4 de março de 2002. Ministério do Meio Ambiente. Instituto Brasileiro do Meio Ambiente e dos Recursos Naturais Renováveis <www.ibama.gov.br/fauna/legislacao/in_04_02. pdf $>$. Accessed on January 4, 2011.

Brasil 2011. Ministério do Meio Ambiente. Instituto Chico Mendes Centro Nacional de Pesquisa e Conservação de Primatas Brasileiros <http:// www4.icmbio.gov.br/cpb/index.php?arquivo=detalhe.php\&pg=0\&id cad_geral=103\&id_menu=104>. Accessed on January 3, 2011.

Castilla K.S., Ferreira C.S.A., Moreno A.M., Nunes I.A. \& Ferreira A.J.P. 2006. Distribution of virulence genes sefC, pefA and $s p v \mathrm{C}$ in Salmonella Enteritidis phage type 4 strains isolated in Brazil. Braz. J. Microbiol. 37:135139.

Chomel B.B., Belotto A. \& Meslin F.X. 2007. Wildlife, exotic pets and emerging zoonoses. Emerg. Infect. Dis. 13:6-11.

Clarke R.C. \& Gyles C.L. 1986. Salmonella, p.95-107. In: Gyles C.L. \& Thoen C.O. (Eds), Pathogenesis of Bacterial infections in Animals. Iowa State University Press, Ames.

Cook A.L., St Claire M. \& Sams R. 2004. Use of florfenicol in non-human primates. J. Med. Primatol. 33:127-133.

Favoretto S.R., Mattos C.C., Morais N.B., Araújo F.A.A. A. \& Mattos C.A. 2001. Rabies in Marmosets (Callithrix jacchus), Ceará, Brazil. Emerging Infect. Dis. 7:1062-1065.

Feutrier J., Kay W.W. \& Trust T.J. 1988. Cloning and expression of a Salmonella enteritidis Fibrin Escherichia coli. J. Bacteriol. 170:4216-4222.

Häggblom P., Humplhrey T.J., Heino A. \& Aspan A. 2002. Salmonella Yoruba, an emerging serotype in animal production? Proc. International Symposium Salmonella and Salmonellosis, St Brieux, França, p.333-334. (Abstract)

IUCN 2008. IUCN Red List of Threatened Species <www.iucnredlist.org>. Accessed on January 2, 2011.
Joslin J.O. 2003. Other primates excluding great apes, p.380. In: Fowler M.E. \& Miller R.E. (Eds), Zoo and Wild Animal Medicine. $5^{\text {th }}$ ed. W.B. Saunders, Philadelphia.

Michael G.B., Simoneti R., Costa M. \& Cardoso M. 2003. Comparison of different selective enrichment steps to isolates Salmonella sp. from feces of finishing swine. Braz. J. Microbiol. 34:138-142.

Montali R.J. \& Bush M. 1999. Diseases of the callithrichidae, p.371-372. In: Fowler M.E. \& Miller R.E. (Eds), Zoo and Wild Animal Medicine. $4^{\text {th }}$ ed. W.B. Saunders, Philadelphia.

Ogunniyi A.D., Kotlarski I., Morona R. \& Manning P.A. 1997. Role of SefA subunit protein of SEF14 the pathogenesis of Salmonella enteric serovar Enteritidis. Infect. Immun. 65:708-717.

Osterberg J., Ekwall S.J., Nilsoon I., Stampe M., Engval A. \& Wallgren P. 2001. Erradication of Salmonella Yoruba in an integrated pig herd. Tierärztl. Wochenschr. 114:331-334.

Osterberg J. \& Wallgren P. 2008. Effects of a challenge dose of Salmonella Typhimurium or Salmonella Yoruba on the patterns of excretion and antibody responses of pigs. Vet. Rec. 162:580-585.

Paul-Murphy J. 1993. Bacterial enterocolitis in nonhuman primates, p.344347. In: Fowler M.E. (Ed.), Zoo and Wild Animal Medicine Current Terapy. $3^{\text {rd }}$ ed. W.B. Saunders, Philadelphia.512p.

Rocha L.T., Thomaz K.F., Teixeira R.H.F., Souza C.A.I. \& Knöbl T. 2006. Isolamento de Salmonella spp. em primatas neotropicais: avaliação da condição de portador. Anais X Congresso da Associação Brasileira de Veterinários de Animais Selvagens (Abravas), São Pedro, SP, p.30. (Abstract)

Salehi T.Z., Mahzounieh M. \& Saeedzadeh A. 2005. Detection of invA Gene in isolated Salmonella from Broilers by PCR Method. Int. J. Poult Sci. 4:557559.

Speck S., Pauly A. \& R. Stark. 2007. Fatal case of Salmonella Typhimurium infection in a cherry crowned mangabey(Cercocebus torquatus). Verhandlungen über. Erkrankungen der Zootiere 43:321-324.

SPZO0 2011. Programa de Quarentena <www.spzoo.org.br/quarentena. htm>. Accessed on January 4, 2011.

Swamy S.C., Fierer J. \& Guiney D.G. 1992. Characterization of translation terminal mutations in the spv operon of the Salmonella virulence plasmid Psdl2. J. Bacteriol. 174:6418-6423.

Verona C.E.S. \& Pissinatti A. 2006. Primates: Primatas do Novo Mundo (Sagüi, macaco-prego, macaco-aranha, bugio), p.358-377. In: Zalmir C.S., Silva J.C.R. \& Catão-Dias J.L. (Eds), Tratado de Animais Selvagens: medicina veterinária. Roca, São Paulo.

Vilani R.G.D.C. 2006. Estrutura hospitalar, quarentenário e Centros de Triagem, p.37-41. In: Zalmir C.S., Silva J.C.R. \& Catão-Dias J.L. (Eds), Tratado de Animais Selvagens: medicina veterinária, Roca, São Paulo. 